\title{
Prisoners' expectations of the national forensic DNA database: Surveillance and reconfiguration of individual rights
}

\author{
Helena Machado ${ }^{\mathrm{a}, 1, *}$, Filipe Santos ${ }^{\mathrm{b}, 2}$, Susana Silva ${ }^{3, \mathrm{c}}$ \\ a Instituto de Ciências Sociais, Departamento de Sociologia, Campus de Gualtar, 4710-057 Braga, Portugal \\ b Centro de Estudos Sociais, Colégio de S. Jerónimo, Apartado 3087, 3001-401 Coimbra, Portugal \\ ${ }^{\mathrm{c}}$ Instituto de Saúde Pública da Universidade do Porto (ISPUP), Serviço de Higiene e Epidemiologia, Faculdade de Medicina da Universidade do Porto, R. das Taipas, n. ${ }^{\circ} 135$, \\ 4050-600 Porto, Portugal
}

\section{A R T I C L E I N F O}

\section{Article history:}

Received 13 July 2010

Received in revised form 23 November 2010

Accepted 20 February 2011

Available online 16 March 2011

\section{Keywords:}

Prisoners

Stigma

DNA profile

\begin{abstract}
A B S T R A C T
In this paper we aim to discuss how Portuguese prisoners know and what they feel about surveillance mechanisms related to the inclusion and deletion of the DNA profiles of convicted criminals in the national forensic database. Through a set of interviews with individuals currently imprisoned we focus on the ways this group perceives forensic DNA technologies. While the institutional and political discourses maintain that the restricted use and application of DNA profiles within the national forensic database protects individuals' rights, the prisoners claim that police misuse of such technologies potentially makes it difficult to escape from surveillance and acts as a mean of reinforcing the stigma of delinquency. The prisoners also argue that additional intensive and extensive use of surveillance devices might be more protective of their own individual rights and might possibly increase potential for exoneration.
\end{abstract}

Crown Copyright @ 2011 Published by Elsevier Ireland Ltd. All rights reserved.

\section{Introduction}

Current state concerns with crime control and the securitisation have led an increasing number of governments to invest in a variety of new bio-information technologies to manage the risks posed by criminal elements and terrorist groups. Chief amongst these new bio-information technologies has been DNA profiling or DNA fingerprinting, frequently described as the greatest breakthrough in forensic science since fingerprinting and as the gold standard for individual identification. Following the earlier widespread adoption in many other European countries, in February 2008, the Portuguese law for the forensic DNA database for criminal identification was passed [1]. The database is expected to become operational during 2010.

The regulation of the Portuguese forensic DNA database is more restrictive in terms of data inclusion and information preservation than other European countries [2]. Unlike some countries that do not

\footnotetext{
* Corresponding author. Tel.: +351 253604212; fax: +351 253676966.

E-mail addresses: hmachado@ics.uminho.pt (H. Machado), filipesantos@ces.uc.pt (F. Santos), susilva@med.up.pt (S. Silva).

1 Address: Research Centre for the Social Sciences, University of Minho, Portugal; Centre for Social Studies, University of Coimbra, Portugal.

2 Address: Centre for Social Studies, University of Coimbra, Portugal. Tel.: +351239855 570; fax: +351239855 589 .

${ }^{3}$ Address: Institute of Public Health of University of Porto, Department of Hygiene and Epidemiology, University of Porto Medical School, Portugal. Tel.: +351 2061820; fax: +3512061821.
}

remove profiles from the DNA database for criminal investigation purposes, Portuguese legislation sought to protect the possibility of each and every individual of having a "clean slate" in society, "free" from any sort of official record that, in a direct manner, may associate the individual with a crime committed in the past.

As one of the most effective tools in crime detection currently available, the creation and organization of forensic DNA databases also involves potential threats to a range of individual rights, such as the right to privacy, the right to liberty, the right to moral and physical integrity, the dignity of individuals and the presumption of innocence.

From the point of view of surveillance studies, DNA databases can represent one of the instances by which new and effective modes of social control have been configured and associated to political and governmental crime prevention and control strategies. The storage of individuals' DNA profiles in a database enables a greater surveillance focus on potential offenders and re-offenders within societies that are less tolerant towards suspect citizens [3] and which is made easier by public support of the fight against crime.

The adoption by state surveillance practices of scientific and technological devices for corroborating or inferring identities [4] has been examined by a considerable body of debate and research, such as the studies of history of state identification [5] and the coproduction of surveillance technologies and genetic suspects [6-8] the work on the increasing use of forensic sciences in support of criminal investigations [9-11]; "dataveillance" [12]; and visibility and new forms of surveillance [13-16]. Williams and Johnson $[4,17]$ have made fundamental contributions to describing and 
understanding the novel and powerful form of bio-surveillance offered by DNA profiling and database as a developing instrumentality of modern state surveillance. The forensic DNA databases also constitute "centres of calculation" [18] whose installation marks the expansion of bureaucratic surveillance in contemporary society as part of a bio-surveillance apparatus.

This research work is supplemented by the existence of one single published study carried out in Austria on the prisoners' knowledge about forensic DNA technologies and their expectations with regard to the inclusion of criminals' DNA profiles in the database for the purposes of criminal investigation [19]. This paper aims to provide additional understanding of the prisoners' knowledge and social images concerning the co-production [8] of surveillance and DNA profiling and databasing. In particular, we discuss how Portuguese prisoners know and what they feel about surveillance mechanisms related to the inclusion and removal of the DNA profiles of convicted criminals in the national forensic database. We argue that this represents a form of "governmentality" [20], that is, the social uses of DNA databases for forensic purposes impacts on self management of those whose actions and identities are monitored in this way under such scrutiny.

Following the seminal work on biopolitics [21] and biosociality [22], Lynch and McNally [8] proposed the concept of "biolegality", that is, the creation of a symbiotic relationship between law and biotechnology through which an ongoing process redefines the rights and status of the suspect body and of criminal evidence. The authors discuss how biolegality operates by creating suspect identities [8]. They also argue that "although 'selves' are deeply implicated, suspect identity is primarily an object and product of policing and forensic expertise, rather than a technically defined basis for the formation of individual and group identity" [8].

This paper aims to produce a contribution in the area of surveillance studies by considering three important aspects: first, because it takes the standpoint of the surveillance subjects [23] by inquiring into prisoners' experiences and/or expectations of state surveillance related to the information gathering and storage of DNA profiles for the purposes of criminal investigation. Second, it proceeds to understanding the heterogeneous elements that exist within surveillance practices, through a focus on the dynamics of submission and resistance to DNA forensic technologies developed by criminal bodies. Third, it deconstructs the idea that devices of surveillance and control through DNA databasing have a purely negative character, by arguing that ex-prisoners might feel more liberated and protected from control and repression by being subject to surveillance.

\section{Methods}

After obtaining authorization from the General Board of Prison Services in 2009, we conducted 31 semi-structured interviews to inmates in three prisons for male adults in the north of Portugal between May and September 2009. The interviews took $34 \mathrm{~min}$ on average and were conducted by three trained interviewers.

We devised a theoretical sample, based on representativeness by diversity and exemplariness [24], and conjugated with a convenience sampling by considering the individuals that would be more predisposed to participate in this study according to the information gathered by the administration in each prison. Thus, we obtained a diversified sample in terms of criminal record (type of crime and duration of the sentencing) and socio-demographic characterization (Table 1).

Table 1

Sample characteristics.

\begin{tabular}{|c|c|c|c|c|c|}
\hline Prisoner & Age & $\begin{array}{l}\text { Years of } \\
\text { schooling }\end{array}$ & Professional occupation & Primary crime which led to imprisonment & Sentence \\
\hline David & 42 & 6 & Construction/Manager & Attempted homicide & 3 years and 10 months \\
\hline João & 49 & 4 & Stonemason & Rape, assault & $\begin{array}{l}4 \text { years, } 13 \text { months } \\
\text { and } 100 \text { days }\end{array}$ \\
\hline Carlos & 52 & 4 & Auto Electrician & $\begin{array}{l}\text { Procurement, rape, aggravated rape, child and } \\
\text { drug trafficking, sexual abuse }\end{array}$ & 7 years and 6 months \\
\hline Joel & 22 & 9 & $\begin{array}{l}\text { Industrial Weaver operator/ } \\
\text { Unemployed }\end{array}$ & Aggravated rape & 5 years and 6 months \\
\hline Joaquim & 49 & 6 & Joiner & Severe sexual abuse of minors & 6 years \\
\hline Amaro & 40 & 4 & Agriculture & Homicide and attempted homicide & 20 years \\
\hline Gaspar & 39 & 9 & $\begin{array}{l}\text { Bricklayer's assistant/ } \\
\text { Unemployed }\end{array}$ & Burglary, drug use, theft & 5 years and 6 months \\
\hline António & 26 & 1 & Pastry man & Trafficking and other illegal activities & 5 years \\
\hline Manuel & 27 & $>12$ & Student & Homicide and drug trafficking & 14 years \\
\hline Martim & 27 & 4 & Ironmonger & Rape, attempted coercion, kidnapping & 9 years and 3 months \\
\hline Mariano & 29 & 6 & Plumber & Homicide & 17 years \\
\hline Jaime & 29 & 6 & Construction worker & Homicide & 16 years \\
\hline Daniel & 36 & $>12$ & Bar bouncer & Homicide and attempted homicide, arson & 24 years \\
\hline Tomás & 28 & 9 & Water-proofing worker & Rape and homicide & 21 years \\
\hline Gil & 33 & 7 & Businessman & Trafficking and other illegal activities & 6 years \\
\hline Ovídio & 33 & $>12$ & Plasterer/Businessman & Drug trafficking, possession of an illegal weapon & 8 years \\
\hline Amadeu & 43 & 6 & Bricklayer's assistant & Homicide, burglary, theft & 23 years \\
\hline Nelson & 35 & $>12$ & Security/Vigilance & Sexual abuse of a minor, burglary, theft, perjury & 9 years \\
\hline Micael & 31 & 10 & Undifferentiated worker & $\begin{array}{l}\text { Sexual assault with carnal intercourse and use of } \\
\text { specially dangerous means and rape }\end{array}$ & 12 years and 1 month \\
\hline Emílio & 32 & 9 & Iron worker & Homicide, sexual coercion, theft & 15 years \\
\hline Feliciano & 34 & $>12$ & Construction painter & Homicide & 12 years \\
\hline Artur & 38 & 6 & Electrician & Aggravated burglary, burglary, attempted aggravated theft & 12 years \\
\hline Frederico & 54 & 6 & Retailer & Criminal organization (leader), extortion, drug trafficking, fencing & 20 years \\
\hline Valter & 25 & 6 & Electrician/Unemployed & Kidnapping, rape, burglary, aggravated burglary & 18 years \\
\hline Luís & 26 & 8 & $\begin{array}{l}\text { Carpenter's assistant/ } \\
\text { Electrician }\end{array}$ & Aggravated burglary, motor vehicle theft, trespassing, fencing & 9 years \\
\hline Amândio & 31 & 9 & Driller & $\begin{array}{l}\text { Homicide and attempted homicide, drug trafficking, } \\
\text { theft, aggravated burglary }\end{array}$ & 25 years \\
\hline Rúben & 31 & $>12$ & Computer Systems Analyst & $\begin{array}{l}\text { Aggravated fraud, document forgery, illegal access to a } \\
\text { computer system or network, credit card fraud, perjury }\end{array}$ & 6 years \\
\hline Olegário & 31 & 6 & Paver & Theft and perjury & 3 years and 6 months \\
\hline Henrique & 37 & 4 & Construction blacksmith & Burglary and forgery & 3 years \\
\hline Miguel & 44 & $>12$ & Auto mechanic & Driving without permit & 5 months \\
\hline Lucílio & 34 & 10 & Construction foreman & Driving without permit & 2 years \\
\hline
\end{tabular}


The content analysis of the interviews, the interpretation of results, and the elaboration of conclusions were based on a qualitative approach, trying to associate substantive analysis with theoretical construction [25]. Based on the scientific literature on the subject, from which we highlight the similar study carried out in Austria [19], and the previously established topics of the interview script as well as on the categories which emerged from the interviews themselves, we identified the main issues and concepts.

The collected data were systematically compared, contrasted, synthesized and coded according to themes and, within these, by categories, closely following the principles of the grounded theory [26], by which the objective is to raise new concepts from the empirical reality under observation. The findings are reported below with verbatim quotes from interview transcripts using pseudonyms.

\section{Challenging security and threats to ex-convicts' rights}

The added value of the DNA database is said to be translated into a swifter justice system which, thanks to DNA profile matches, now makes it possible to obtain more guilty pleas from suspects, thus saving time and resources [27]. However, the dominant conceptions of the idea of security were defied by some of the participants in this study. For example, Daniel, the only interviewee with a higher education degree, talked about security as an "illusionary" sociopolitical construction that can be manipulated by political power by taking advantage of the media's exploitation of the population's anxieties. The subject of "security paranoia" was brought up by the interviewee when asked if he would consider an expansion of the national forensic DNA database:

Little by little we are moving towards that security paranoia. It's an illusion. Security is an illusion and people haven't figured that out. Whatever television [networks] sell, people like and demand life sentences and death penalties and micro-chips inserted into children because of the abductions.

Daniel also expressed concerns that the possible violation of individual rights would not arise from keeping the DNA profile in the database, but from the misuse of that information. Daniel provided specific examples and possible consequences of the sharing of information with third party entities, such as being rejected by banks when applying for credit and by potential employers, while highlighting the "infinite" potential uses of genetic information:

Nothing should be eliminated from the police records, nor can it be. Information must be kept always, always! It doesn't bother me that on an investigative level they keep the data, and that it is kept until the day I die. It's not that that scares me, it's not that that scares me. What does scare me, in fact, are the uses that might be made of that sort of information.

According to Wallace [28], for any individual, having a DNA profile on a database raises several concerns regarding the possibility of misuse or unauthorized access, threats to genetic privacy or lack of consent for participation in controversial genetic research, in spite of the undisputed potential to convict the guilty and exculpate the innocent. In this sense, the fact that the construction of DNA databases begins with those who are suspect or incarcerated may provide further concerns related to the dangers of trying to predict behaviours through physical and genetic traits and characteristics [29].

\section{The stigma of delinquency and the role of the usual suspects: a plea for a universal database}

The distrust towards the "real" future uses of the forensic DNA database became more evident when the prisoners were asked what they thought about removing the profiles from the database after the offence is expunged from the criminal record. The majority of our interviewees (20 individuals out of 31) were of the opinion that that the profiles should not be removed from the DNA database. ${ }^{4}$

The main emphasis in the discourse of the interviewees was that the database had the potential to exonerate the innocent. In other words, the interviewees felt that retaining the profile in the database was a "guarantee" against police intrusion in their lives following their release from prison, as several interviewees reported that the police tend to round up the "usual suspects" who fit a certain profile with regard to a certain crime. A similar study with prisoners in Austria also indicates that this type of perception regarding police investigative practices might have a cross-cultural and transnational character, rather than being associated to national idiosyncrasies [19].

Jaime argued for the creation of a universal database. Only then would this sort of instrument be totally effective, he said. Both to identify the guilty party and to prove the innocence of others:

There should be a genetic profile of each citizen in the database, for all purposes. Not only to make an identification in order to convict, but also to acquit. To make an identification in a case of abduction, disappearance, whatever. .

Jaime's words deconstructed the general assumption by police detectives, judges, forensic scientists, politicians and the public in general, that databases are used first and foremost to identify those guilty and to incriminate them (for a discussion about the expansion of DNA databases, see [29-34]). In reality, state surveillance practices based on the increasing accumulation of genetic information not only negate or reverse the presumption of innocence [35], but also, as Finn puts it, "they presuppose criminality, deviance and threat as something that is latent in all bodies. This in turn justifies and reinforces increasingly broad and expansive surveillance practices as the focus of the state shifts from the individual body to aggregate populations" [36].

In point of fact, the deletion of prisoners' DNA profiles from the forensic DNA database was seen by the interviewees as a way of reinforcing the role of the "usual suspect". Nelson also argued for the creation of a universal database as a way to prevent the police practices of seeking suspects based on their profile as previous offenders:

I think it's bad that only the prison population has their genetic information there [in the database]. It should apply to everyone. In order to avoid discrimination and even more... we are the scum of society [silence] because for every crime that occurs, they [the police] will immediately go to the ones that are there [in the database]. And then the honest man might pay for the sinner's faults.

The notion of justice underlying this narrative is common among prisoners, who feel that the person who commits a crime must pay for what he/she did, and the innocent must be protected. This correspondence with the dominant cultural norms, social values, dispositions and expectations concerning "suitable" responses of justice to criminal behaviours may contribute to the reconfiguration of prisoners' identity in order to comply with the social order.

The prisoners' previous experiences with the criminal justice system have led them to a particular redefinition of their rights and

\footnotetext{
${ }^{4}$ Interviewees were asked: "According to the law, after some time, the criminal record must be cleared. The same applies to profiles in the national forensic database. What do you think of this law?"
} 
status, by which they face the removal of their DNA profiles from the forensic database as a lost opportunity to prove their innocence, instead of a benefit and an opportunity for a "clean sheet", "cleared" of any official record that could directly identify them as perpetrators of past crime.

Gil talked about a "mark" which condemns him for the rest of his life. He claimed that the official version of the authorities is that the profiles have been removed, but that they do not actually do it. This opinion is shared by the majority of the prisoners interviewed who, based on their own experiences or those of their peers, believed that the police agencies always keep information about their criminal records, and thought that the same may occur with the case of DNA profiles. In the group interviewed we found that the levels of trust in the integrity of the police were generally low. Thus, in order to ensure greater transparency in the criminal investigation procedures, Gil argued that the profiles should never be removed from the DNA database:

Gil: It all stays there. The government doesn't have to tell stories about how they will remove it [the profile] because they won't. It's another proof that the government and the police, in this case regarding criminal investigation - I'm referring to the Polícia Judiciária - don't delete people's records, they keep people's records [criminal records] for the rest of their lives. (...)

Interviewer: Do you think that the information on the database should be deleted or should it remain forever?

Gil: It should remain forever in the database, for the whole life. It's like this, I made the mistake of lending money and no matter how many years I still have ahead of me, I will live with this mark [silence]. How does it help me to remove my profile from the database if I know that I will have to live with this mark for the rest of my life? [silence]. .

The individuals we interviewed conveyed the notion that the increase of surveillance practices could contribute to a better defence of their individual rights and make them feel more protected against discriminatory practices aimed at ex-convicts. In this sense, the solution found by many of the prisoners interviewed to put an end to discrimination between "those who are in the database and those who are not", and also to increase the efficacy of criminal investigation would be to create a universal database, which would include the whole population. Other prisoners argued for the widening of surveillance practices through the expansion of the database's criteria for inclusion, stating that all those convicted should be included, regardless of the crime they committed, the length of their sentence or even if they were given a non-custodial sentence.

\section{Questioning the DNA as a "truth" machine}

The interviewees' argument in favour of the expansion of criteria in the national forensic database to include DNA profiles of all citizens, or at least, all convicted individuals, appears to be grounded on their notion that DNA technologies enable the automatic identification of "offenders". The belief in the "truth" of DNA was not, however, absolute, like the data obtained in interviews with prisoners in Austria [19]. Although the general majority (25 individuals out of 31 ) of those we interviewed perceived DNA as something that, being extracted from the body, can be a unique token for identification, they also believed that the police can set them up and plant evidence at crime scenes to incriminate a suspect.
David pointed out that DNA merely proves that someone had been at a crime scene or that someone planted DNA material of a certain individual. Thus, by itself, DNA evidence is not a synonym for truth:

[With DNA alone] you can't really prove that the person was there or committed the crime. .. the person could have been there earlier and could have lost a hair before the crime. That evidence alone cannot convict anyone. (...)It's not something (...) that is taken as the absolute truth, right? (...) Evidence can be planted, right?

The negative opinion of the criminal justice system revealed by most interviewees concerns judges as much as the criminal investigation police. The interviewees' opinions of judges were that they are biased against poor defendants and that they can be just as incompetent in the appreciation of scientific evidence as in their decision making. Hence, through automation, a DNA database could eliminate the contingencies and discriminations generated by the judges' actions. Similarly, by increasing the speed and efficacy of criminal investigation, the automation of the identification of individuals rendered by the storage and computerization of genetic information could avoid certain police practices aimed at the usual suspects, such as: making unfounded accusations against individuals that have been the target of criminal investigations in the past; using fabricated or illegal incriminating procedures; making use of violence to obtain confessions (mentioned by 3 prisoners) or to collect biological samples; and keeping illegal databases of biological samples or DNA profiles.

Carlos: If they create a database [including] all citizens (...) through the DNA they will automatically identify the individual in question.

From the point of view of surveillance studies, the growing number of databases of DNA profiles represents more extensive means of social control and might represent a risk or a threat to individuals' rights. As Aas puts it, by referring to technological devices for determination of identity, such as DNA profiles and biometric methods, these "new methods [are] less time consuming, they also introduce a new language - a binary language of ones and zeroes which radically reduces possibilities for negotiation and therefore also resistance" [37]. However, our interviewees felt more protected by the automation provided by technology, because of notions that their capacity for resistance and negotiation is strongly hierarchical and it is not possible for them to achieve success in that negotiation. Hence, automation transposes the power of decision and its political character to technology, perceived as neutral and effective, in a form of "mechanical objectivity" which "serves as an alternative to personal trust" [38] and enables the redefinition of the concept of security because it is no longer necessary to prepare defence or resistance strategies [39].

\section{Conclusion}

In this paper we have discussed how individuals themselves might be more implicated in the construction of suspects' identities [40] and in the redefinition of the rights and status of suspect body than is usually described in the literature. We have explored in detail one concrete case of bio-surveillance apparatus by taking into account how knowledge about collection and databasing of DNA profiles has effects on the self-management of those whose action and identities are captured in this specific method of surveillance. This case of bio-surveillance also demonstrated a variant of biolegality [8], whose implications 
were undertaken through the assessment made by the prisoners we interviewed of the regulation of the Portuguese national forensic database and its particular stipulation that the DNA profile of convicted individuals must be removed a maximum of 10 years after the sentence has been served.

This rule illustrates the orientation towards protecting citizens' rights and maximizing the chances of reintegrating delinquents. However, the prisoners we interviewed challenged this assumption by mentioning how the elimination of DNA profiles from the database will contribute to render individuals with prior convictions more vulnerable to surveillance mechanisms, incriminatory practices by the police and processes of targeting them as usual suspects. In addition, they disagreed with the rule of removing the profiles from the DNA database, insofar as they believe that the profiles should be kept in order to enhance the database's efficacy. The importance of self-management of the actions and identities of those who are under surveillance (convicted individuals) seems to contrast deeply with the intentions of those who create legal mechanisms of surveillance (law makers and forensic scientists).

This particular group considered that the restrictive use of the DNA forensic database would increase surveillance and the use of DNA evidence could serve to perpetuate or even deepen their stigma. The reasoning for that argument was based on the fear of potential misuse of these technologies by the police and the criminal justice system and the maintenance of "informal" police databases even after the official removal of profiles of convicted criminals from the national forensic DNA database. They therefore were of the opinion that a broader and more intensive use of the DNA forensic database would be more beneficial and more protective of their individual rights.

\section{Acknowledgments}

We would like to thank the Foundation for Science and Technology (Portuguese Ministry of Science, Technology and Higher Education) for financing this research through a post-doc fellowship (SFRH/BPD/34143/2006), the project "Forensic DNA databasing in Portugal: Contemporary issues in ethics, practices and policy" (FCOMP-01-0124-FEDER-009231) and also the project "Justice, media and citizenship" (FCOMP-01-0124-FEDER007554). We are grateful for the insightful and helpful comments of Barbara Prainsack who provided valuable feedback on earlier drafts of this article and guidance throughout the research. We are also extremely grateful to Diana Miranda for her participation in the fieldwork of this study and to Manuela Ivone Cunha for her collaboration in producing the report of this research to the General Board of Prison Services (Portugal).

\section{References}

[1] Law 5/2008, Approves the creation of a DNA profiles database for civil and criminal identification purposes, Diário da República, series 130 (2008) 962-968.

[2] N. Van Camp, K. Dierickx, National Forensic DNA Databases-Socio-ethical Challenges and Current Practices in the EU, 2007.

[3] D. Lyon, Surveillance Studies: An Overview, Polity Press, Cambridge, 2007.

[4] R. Williams, P. Johnson, Circuits of surveillance, Surveillance \& Society 2 (2004) $1-14$.

[5] J. Caplan, J. Torpey, Documenting Individual Identity: The Development of State Practices in the Modern World, Princeton University Press, Princeton, 2001.

[6] S.A. Cole, Suspect Identities: A History of Fingerprinting and Criminal Identification, Harvard University Press, Harvard, 2002.

[7] M. Lynch, S.A. Cole, R. McNally, Truth Machine: The Contentious History of DNA Fingerprinting, University of Chicago Press, Chicago, 2008.
[8] M. Lynch, R. McNally, Forensic DNA databases: the co-production of law and surveillance technology, in: P. Atkinson, P. Glasner, M. Lock (Eds.), Handbook of Genetics and Society: Mapping the New Genomics Era, Routledge, London, 2009, pp. 283-301.

[9] R. Hindmarsh, B.P. Prainsack, Genetic Suspects: Global Governance of Forensic DNA Profiling and Databasing, Cambridge University Press, Cambridge, 2010

[10] D. Lazer, DNA and the Criminal Justice System: The Technology of Justice, MIT Press, Cambridge, MA, 2004

[11] R. Williams, P. Johnson, P. Martin, Genetic Information and Crime Investigation: Social, Ethical and Public Policy Aspects of the Establishment, Expansion and Police Use of the National DNA Database, Project Report, Durham University, School of Applied Social Sciences, Durham, 2004.

[12] R. Clarke, Information technology and dataveillance, Communications of the ACM 31 (1988) 498-512.

[13] D. Lyon, The new surveillance: electronic technologies and the maximum security society, Crime, Law and Social Change 18 (1992) 159-175.

[14] D. Lyon, Surveillance Society: Monitoring Everyday Life, Open University Press, Buckingham, 2001.

[15] D. Lyon, Editorial. Surveillance studies: understanding visibility, mobility and the phonetic fix, Surveillance \& Society 1 (2002) 1-7.

[16] G. Marx, What's new about the "new surveillance"?: classifying for change and continuity, Surveillance \& Society 1 (2002) 9-29.

[17] R. Williams, P. Johnson, Genetic Policing: The Use of DNA in Criminal Investigations, Willan Publishing, Cullompton, 2008.

[18] B. Latour, Centres of calculation, in: B. Latour (Ed.), Science in Action: How to Follow Scientists and Engineers Through Society, Harvard University Press, Cambridge, MA, 1987, pp. 215-257.

[19] B. Prainsack, M. Kitzberger, DNA behind bars: other ways of knowing forensic DNA technologies, Social Studies of Science 39 (2009) 51-79.

[20] M. Foucault, On governmentality, Ideology and Consciousness (1979) 5-26.

[21] M. Foucault, The History of Sexuality. Vol. 1: The Will to Knowledge, Penguin, London, 1978

[22] P. Rabinow, Afterword: concept work, in: S. Gibbon, C. Novas (Eds.), Biosocialities, Genetics and the Social Sciences: Making Biologies and Identities, Routledge, London, 2008, pp. 188-192.

[23] K.T. Walby, Institutional ethnography and surveillance studies: an outline for inquiry, Surveillance \& Society 3 (2005) 158-172.

[24] J. Hamel, S. Dufour, D. Fortin, Case Study Methods, Sage Publications, London, 1993.

[25] S. Becker, A. Bryman, Understanding Research for Social Policy and Practice: Themes Methods and Approaches, The Policy Press, Bristol, 2004.

[26] B.G. Glaser, A.L. Strauss, The Discovery of Grounded Theory: Strategies for Qualitative Research, Aldine de Gruyter, New York, 1967.

[27] C. McCartney, Forensic DNA Sampling and the England and Wales National DNA Database: a sceptical approach, Critical Criminology 12 (2004) 157-178.

[28] H. Wallace, Prejudice, stigma and DNA databases, in: Council for Responsible Genetics, 2008, pp. 1-19.

[29] T. Duster, Selective arrests, an ever-expanding DNA forensic database and the specter of an early-twenty-first-century equivalent of phrenology, in: D. Lazer (Ed.), DNA and the Criminal Justice System: The Technology of Justice, MIT Press, Cambridge, MA, 2004, pp. 315-334.

[30] M. Guillén, Ethical-legal problems of DNA databases in criminal investigation, Journal of Medical Ethics 26 (2000) 266-271.

[31] D.H. Kaye, M.E. Smith, DNA databases for law enforcement: the coverage question and the case for a population-wide database, in: D. Lazer (Ed.), DNA and the Criminal Justice System: The Technology of Justice, MIT Press, Cambridge, MA 2004, pp. 247-284

[32] A.A. Noble, DNA fingerprinting and civil liberties, Journal of Law, Medicine \& Ethics 34 (2006) 149-152.

[33] M.E. Smith, Let's make the DNA identification database as inclusive as possible, Journal of Law, Medicine \& Ethics 34 (2006) 385-389.

[34] R. Williams, P. Johnson, 'Wonderment and dread': representations of DNA in ethical disputes about forensic DNA databases, New Genetics and Society 23 (2004) 205-223.

[35] D. Lyon, The Electronic Eye: The Rise of Surveillance Society, Polity Press, Oxford, 1994.

[36] J. Finn, Photographing fingerprints: data collection and state surveillance, Surveillance \& Society 3 (2005) 21-44.

[37] K. Aas, 'The body does not lie': identity, risk and trust in technoculture, Crime, Media, Culture 2 (2006) 143-158.

[38] T.M. Porter, Trust in Numbers: The Pursuit of Objectivity in Science and Public Life, Princeton University Press, Princeton, 1996.

[39] M. Kanashiro, Surveillance cameras in Brazil: exclusion, mobility regulation, and the new meanings of security, Surveillance \& Society 5 (2008) 270-289.

[40] S Cole, M. Lynch, The social and legal construction of suspects, Annual Review of Law and Social Science 2 (2006) 39-60. 